\title{
Morphological variation in Atractustartarus (Serpentes: Dipsadidae) from the Xingu River, east Amazon, Brazil and preliminary phylogenetic relationship in Atractus
}

\author{
Elciomar Araújo De Oliveira ${ }^{1}$, Emil José Hernández Ruz ${ }^{* 2}$ \\ 1 Programa de Pós-graduação em Biodiversidade e Biotecnologia da Rede Bionorte, Universidade \\ Federal do Amazonas, Av. Gen. Rodrigo Octávio Jordão Ramos, Brazil \\ 2 Programa de Pós-Graduação em Biodiversidade e Conservação, Faculdade de Ciências Biológicas, \\ Campus Universitário de Altamira, Universidade Federal do Pará, Rua Coronel José Porfírio, São \\ Sebastião, Brazil. \\ elciomar.atractus@gmail.com,*emilhjh@yahoo.com
}

\begin{abstract}
Currently are recognized 138 species in the genus Atractus, distributed from the eastern region of the Isthmus of Panama to northern Argentina. In recent years, many species have been described based on external morphological differences and hemipenis. Here we described the variation in meristic character in the newly described specie Atractus tartarus from the eastern Brazilian Amazon from the Xingu region. Additionally we present a preliminary hypothesis of relationship with your relatives, based on marker 16SmtDNA.
\end{abstract}

Keyword: Molecular, Snakes, Atractus tartarus.

Abbreviations: Snout-Vent Length (SVL); Total Length (TTL); Tail Length (TL); Head Width (HW) defined as the widest part of the head; Head length (HL), definite the tip of the rostral scale to the joint angle of the square bone.

\section{INTRODUCTION}

The genus Atractus Wagler 1828, currently has 138 species [1], and is considered the richest in number of species of snakes [2,3]. Is distributed from the eastern region of the Isthmus of Panama to northern Argentina [4]. Within the main studies with genus in the Amazon we emphasize the [4] to Ecuador; [5] for Suriname; [6] for central Brazilian Amazon in Manaus region; [7] and [8] for the Colombian Amazon and [9] to Guyana and Venezuela. The taxonomy of this genus has long been based on external morphological characters as coloration pattern and cephalic plates $[4,5,10]$, recently being incorporated data as hemipenis [7, 3].

In the last decade, many species have been described based on traditional morphological characteristics and/or hemipenis: Brazil [11, 12, 13, 14], Colombia [15] and Ecuador [16]. With respect to hemipenis, [4] defined two forms of this structure to Atractus Ecuador: 1) undifferentiated, entirely covered with small spines willing in longitudinal lines; 2) differentiated with the center of the body forming two areas, one distal and another basal.[4] also proposed the aggrupation of the genus into three groups: A. badius (Boie 1827), A. elaps (Gunther 1858) and A. trilineatus Wagler 1828, based on characters scalation, dentition and rows of dorsal scales.

Here we describe the variation in meristic characters within species Atractus tartarus Passos, Prudente and Lynch 2016, with 15 rows dorsal scales for Volta Grande do Xingu, Pará State, Brazil, and a proposal a preliminary hypothesis of phylogenetic relationships regarding the congeneric species based on 16S mtDNA fragment.

\section{MATERIAL AND METHODS}

Total genomic DNA was extracted by phenol-chloroform protocol [17] and resuspended with $30 \mu \mathrm{L}$ of TE. DNA quality was verified by agarose gel electrophoresis. Polymerase Chain Reaction (PCR) was performed to amplify a fragment of $497 \mathrm{bp}$ of the $16 \mathrm{~S}$ mitochondrial gene. The PCR to fragment of the $16 \mathrm{~S}$ mitochondrial gene (total volume of $15 \mu \mathrm{L}$ ) contained $6.7 \mathrm{ddH}_{2} \mathrm{O} \mu \mathrm{L}, 1.5 \mathrm{uL}$ of $25 \mathrm{mM}$ $\mathrm{MgCl}_{2}, 25.1 \mu \mathrm{L}$ of $10 \mathrm{mM}$ dNTPs $(2.5 \mathrm{mM}$ each dNTP), $25.1 \mu \mathrm{L}$ of $10 \mathrm{x}$ buffer ( $75 \mathrm{mM}$ Tris HCl, 50 $\left.\mathrm{mM} \mathrm{KCl}, 20 \mathrm{mM}\left(\mathrm{NH}_{4}\right)_{2} \mathrm{SO}_{4}\right), 1.5 \mu \mathrm{L} 16 \mathrm{~S}$ A primer (5'-CGCCTGTTTACCAAAAACATCGCCT-3'), 
$1.5 \mu \mathrm{L}$ 16S B primer (5'-CCGGTCTGAACTCAGATCACGT-3') [18], $0.3 \mu \mathrm{L}$ of 1 U Taq polymerase, and $1 \mu \mathrm{L}$ of DNA (30 - $50 \mathrm{ng} / \mu \mathrm{L})$ under the following conditions: an initial temperature of $92^{\circ} \mathrm{C}(60$ sec.), followed by 35 cycles of $92^{\circ} \mathrm{C}(60 \mathrm{sec}),. 50^{\circ} \mathrm{C}(50 \mathrm{sec}$.$) and 72^{\circ} \mathrm{C}(1.5 \mathrm{~min}$.$) and a final$ extension at $72^{\circ} \mathrm{C}$ for $7 \mathrm{~min}$.

The sequencing reactions were performed using BigDye terminator kit as (Applied Biosystems).

Following the manufacturer's protocol. The primer forward 16S A (mtDNA), it was used in the sequencing reaction. The products of the sequencing reactions were precipitated with ethanol according to manufacturer's recommendations, resuspended in $10 \mathrm{uL}$ of deionized formamide (ABI) and subsequently injected into the 3130xl ABI automated sequencer (Applied Biosystems).

For the construction of the phylogenetic tree was obtained a total of $472 \mathrm{bp}$ of a specimen of Atractus tartarus the region of Volta Grande do Xingu, Pará State, Brazil. Additionally GenBank sequences were obtained from several species of Atractus and Tretanorhinus variabilis Duméril, Bibron and Duméril 1854, as the external group (Table 1). All sequences were aligned using the algorithm Clustal $\mathrm{W}$ [19] implemented in software BIOEDIT 7.2 [20]. The evolutionary molecular model TIM $2+\mathrm{I}+\mathrm{G}$ was chosen through software jModelTest [21] and a phylogenetic tree Maximum Likelihood (ML) with 10,000 replicas bootstrap was generated in software TREEFINDER [22]. The genetic distance pairwise uncorrected (p-distance) between species were calculated in MEGA 6.0 software [23].

Table 1: GenBank species accession used for molecular comparison with species Atractustartarusin this study

\begin{tabular}{|c|c|}
\hline Species & $\mathrm{N}^{\mathrm{o}}$ in GenBank \\
\hline Atractus albuquerquei & GQ457726.1 \\
\hline A. duboisi & KT944041.1 \\
\hline A. dunni & |KT944038.1 \\
\hline A. gigas & KT944043.1 \\
\hline A. iridescens & KT944039.1 \\
\hline A. major & KT944045.1 \\
\hline A. resplendens & KT944042.1 \\
\hline A. schach & AF158486.1 \\
\hline Atractus sp. & KT944040.1 \\
\hline A. trihedrurus & GQ457727.1 \\
\hline A. typhon & KT944044.1 \\
\hline A. zidocki & AF158487.1 \\
\hline Tretanorhinus variabilis & AF158529.1 \\
\hline
\end{tabular}

The specimens are derived from environmental monitoring studies and were donated to the Universidade Federal do Pará (UFPA), campus de Altamira. The abbreviations used are: Snout-Vent Length (SVL); Total Length (TTL); Tail Length (TL); Head Width (HW) defined as the widest part of the head; and Head length (HL), definite the tip of the rostral scale to the joint angle of the square bone. The SVL, TTL and TL were measured with a flexible tape measure $100 \mathrm{~cm}$ length. All other measures were taken with the help of a digital caliper $0.01 \mathrm{~mm}$ of the brand Mitutoyo ${ }^{(\mathrm{R})}$. Morphological descriptions and type of cephalic scales follow the literature [4, 14, 15]. The measurements of the structures pairs, were performed on the left side of the body [15]. The sex was identified by observing the hemipenis. The description of hemipenis was made using the terminology of [4] and [24].

Due we do not have access to specimen type da specie A.tartarus, we used the original descriptions of [25] to be compared with the specimensstudied here.

\section{RESUlTS AND DISCUSSION}

\section{Atractus tartarus}

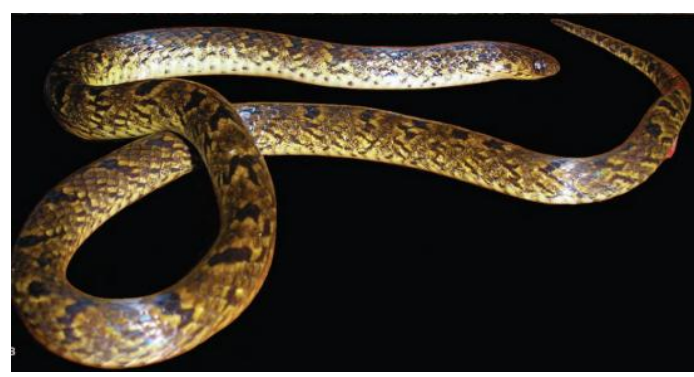

Figure1. Holotype of Atractus tartarus collected in vila Palestina, state of Pará - Brazil (Passos et al. 2016). 
Morphological variation in Atractus tartarus of (Snake: Dipsadidae) from the Xingu River, East Amazon, Brazil and Preliminary Phylogenetic Relationship in Atractus

Holotype: Adult male (MNRJ 16511) collected by R.S. Bérnils, H. Wogel, and P.S. Abe on 07

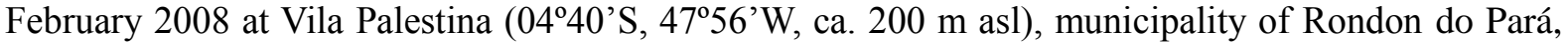
state of Pará, Brazil.

Specimens in this Study: Male, LZATM 935 and female, LZATM 946, collected in the region known as Volta Grande do Xingu, Pará State, Brazil ( $3^{\circ} 15^{\prime} 57,1^{\prime \prime} \mathrm{S}$ and $\left.51^{\circ} 57^{\prime} 25,03^{\prime} \mathrm{W}\right)$ in 02/10/2013 by environmental consulting firm.

Variation in Meristic and Morphometric Characters (in parenthesis): Seven infralabial (six infralabial); ventral scales 146 - 157 in male (158 ventral scales); subcaudal 29 - 38 in male (39 scales subcaudal); scale subcaudal 23 - 31 in female (32 scales subcaudal in female); long tail in males varying from $15.5-18.1 \%$ of SVL (18.31\% of SVL). The measurement values of all variables are in the supplementary material Table 2.

Molecular data: Based on mitochondrial 16S we find a phylogenetic relationship with low values support (Figure 2), probably due to small number of available sequences in GenBank to the species of Atractus. However, we observe that the species with 15 rows of dorsal scales does not represent a monophyletic group, and the specie A. tartarus is more phylogenetically related to species Atractus trihedrurus (Amaral 1926) what has 17 rows of dorsal scales. With respect to genetic distance, the specie having from $4-6 \%$ (Table 3) differences for other species, values that are much larger than those found for other species, e.g. Atractus resplendens Werner 1901 and A. duboisi (Boulenger 1880) they have $2 \%$ of interspecific genetic distance.

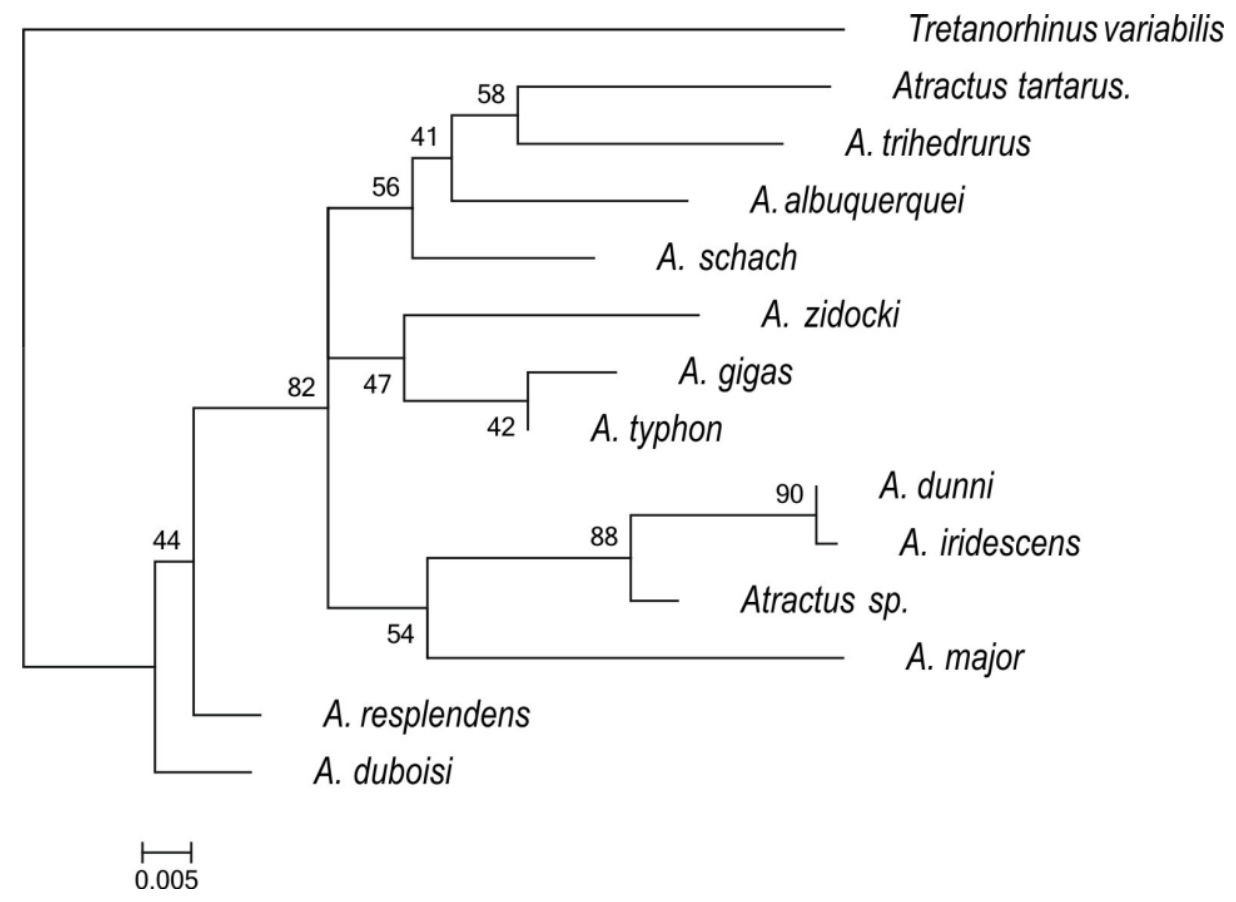

Figure2. Maximum likelihood tree showing a hypothesis phylogenetic relationship between species 17/17/17 and 15/15/15 rows of dorsal scales of genus Atractus, based on 16S mitochondrial marker.

Table2. Values of morphometric variables in mm of the two species in study

\begin{tabular}{|l|l|l|}
\hline Meristic characters/morphometry & Male & Female \\
\hline Snout-Vent Length & 350 & 450 \\
\hline Length Tail & 64.09 & 52.81 \\
\hline Total Length & 414.09 & 502.81 \\
\hline Length Head & 10.88 & 12.94 \\
\hline Width Head & 7 & 9.75 \\
\hline Nose To Eye & 3.02 & 3.38 \\
\hline Rostro To Eye & 4.36 & 4.84 \\
\hline Intraorbital & 4.61 & 5.64 \\
\hline Width Rostral & 2.49 & 2.46 \\
\hline Height Rostral & 1.29 & 1.72 \\
\hline Width Internasal & 1.36 & 1.47 \\
\hline
\end{tabular}


Elciomar Araújo De Oliveira \& Emil José Hernández Ruz

\begin{tabular}{|c|c|c|}
\hline Height Internasal & 1.06 & 1.21 \\
\hline Suture Internasal & 0.62 & 0.95 \\
\hline Width Pre Front & 2.20 & 2.73 \\
\hline Length Pre Front & 2.40 & 3.25 \\
\hline Length of Scale Front & 3.72 & 4.09 \\
\hline Width Front Of Scale & 3.49 & 3.95 \\
\hline Length Supraocular & 1.83 & 2.33 \\
\hline Width Supraocular & 1.31 & 1.88 \\
\hline Length Parietal & 5.47 & 5.80 \\
\hline Width Parietal & 3.86 & 3.60 \\
\hline Length Pre Nasal & 0.87 & 1.09 \\
\hline Width Pre Nasal & 1.39 & 1.42 \\
\hline Length Post Nasal & 0.94 & 0.71 \\
\hline Width Post Nasal & 1.30 & 1.29 \\
\hline Length Loreal & 2.25 & 2.83 \\
\hline Height Loreal & 1.08 & 1.16 \\
\hline Diameter Eye & 2.10 & 2.31 \\
\hline Height Post Ocular Upper & 0.79 & 1.20 \\
\hline Length Post Ocular Upper & 0.80 & 0.99 \\
\hline Height Post Ocular Lower & 1.16 & 1.33 \\
\hline Length Post Ocular Lower & 0.67 & 0.80 \\
\hline Length Temporal Previous & 2.29 & 2.75 \\
\hline Width Temporal Previous & 1.52 & 2.14 \\
\hline Posterior Superior Temporal Length & 2.57 & 4.82 \\
\hline Posterior Superior Temporal Width & 1.80 & 2.95 \\
\hline Length Seventh Supralabial & 2.46 & 2.25 \\
\hline Width Seventh Supra Labial & 1.84 & 2.52 \\
\hline Width Mental & 1.79 & 2.09 \\
\hline Height Mental & 0.75 & 0.95 \\
\hline Length Mentonianas & 4.47 & 4.44 \\
\hline Width Mentonianas & 1.80 & 1.96 \\
\hline Scales Ventrals & 158 & 169 \\
\hline Scales Subcaudal Split & 39 & 32 \\
\hline Dorsal Scales & $15 / 15 / 15$ & $15 / 15 / 15$ \\
\hline
\end{tabular}

Table3. Genetic distance (\%) pairwise uncorrected between species Atractus based on molecular marker $16 \mathrm{~s}$

\begin{tabular}{|c|c|c|c|c|c|c|c|c|c|c|c|c|c|}
\hline Species & 1 & 2 & 3 & 4 & 5 & 6 & 7 & 8 & 9 & 10 & 11 & 12 & 13 \\
\hline \multicolumn{14}{|l|}{ A. tartarus -1} \\
\hline A. albuquerquei -2 & 0,04 & & & & & & & & & & & & \\
\hline A. duboisi - 3 & 0,05 & 0,06 & & & & & & & & & & & \\
\hline A. dunni - 4 & 0,06 & 0,05 & 0,05 & & & & & & & & & & \\
\hline A. gigas -5 & 0,05 & 0,04 & 0,05 & 0,06 & & & & & & & & & \\
\hline A. iridescens - 6 & 0,06 & 0,05 & 0,06 & 0,00 & 0,07 & & & & & & & & \\
\hline A. major - 7 & 0,06 & 0,06 & 0,07 & 0,06 & 0,06 & 0,06 & & & & & & & \\
\hline A. resplendens -8 & 0,04 & 0,05 & 0,02 & 0,05 & 0,04 & 0,05 & 0,06 & & & & & & \\
\hline A. schach-9 & 0,05 & 0,04 & 0,05 & 0,06 & 0,05 & 0,06 & 0,07 & 0,04 & & & & & \\
\hline Atractus sp. - 10 & 0,06 & 0,04 & 0,05 & 0,03 & 0,05 & 0,03 & 0,05 & 0,05 & 0,05 & & & & \\
\hline A. trihedrurus - 11 & 0,05 & 0,04 & 0,06 & 0,06 & 0,05 & 0,06 & 0,08 & 0,05 & 0,04 & 0,05 & & & \\
\hline A. typhon - 12 & 0,04 & 0,04 & 0,04 & 0,06 & 0,01 & 0,06 & 0,06 & 0,04 & 0,04 & 0,05 & 0,04 & & \\
\hline A. zidocki - 13 & 0,05 & 0,06 & 0,05 & 0,07 & 0,04 & 0,07 & 0,06 & 0,05 & 0,05 & 0,06 & 0,07 & 0,04 & \\
\hline T. variabilis -14 & 0,08 & 0,07 & 0,07 & 0,09 & 0,07 & 0,09 & 0,09 & 0,07 & 0,08 & 0,07 & 0,08 & 0,07 & 0,09 \\
\hline
\end{tabular}

Atractus tartarus is part of the group of species Atractus with 15 dorsal scales rows. The species that share this condition in the dorsal scales are derived regarding those with 17 rows of dorsal scales [4]. Due to fossorial habit, becomes difficult to found with several specimens of the genus. [25] founding 16 specimens, but none had the variations recorded here. Works that link variations in morphological characters used to identify species of snakes, are important to better understand the phenotypic plasticity within a species. 
[25] proposes the creation of a new group of species, group Atractus flammigerus, including the species: Atractusatratus (Passos and Lynch 2010), A. flammigerus (Boie, 1827), A.fuliginosus (Hallowell 1845), A. major (Boulenger 1894), A. punctiventris Amaral 1933, A. schach (Boie 1827), A. snethlageae Cunha and Nascimento 1983, A. tartarus and A. univittatus (Jan 1862). This group, with the exception of $A$. tartarus and A. punctiventris, share 17/17/17 rows of dorsal scales. Our molecular data showed that A. tartarus it is more related to the species Atractus trihedrurus, that presents 17/17/17 rows of dorsal scales, revealing a paraphyletic group.

Atractus tartarus represents a species of a mega-diverse genus with about 138 species [1], we believe that with the use of molecular markers (mtDNA), this number may increase due to the probable existence of cryptic species. Despite the recognized effectiveness of the use of genetic markers to identify cryptic species of frogs [26, 27], lizards [28, 29] and snakes [30, 31] the use of this tool is still a taboo in studies with Atractus, which has pronounced morphological conservatism, except in color pattern [32].

\section{ACKNOWLEDGEMENTS}

Many thanks to Professor Evonnildo Gonçalves the Universidade Federal do Pará/Campus de Belém for help in obtaining the sequence of the $16 \mathrm{~S}$ gene in its Biotechnology Laboratory and sequencing the Instituto Evandro Chagas and the entire staff of his laboratory who helped in any part of this process.

\section{ADDITIONAL INFORMATION (DATA OBTAINED FROM THE LITERATURE)}

Atractus tartarus - Brazil: Pará: Vila Palestina. MNRJ 16511 (holotype);

Atractus albuquerquei - Brazil: Pará: Vila Nova. MPEG 12946 (holotype);

Atractus spinalis - Brazil: Minas Gerais: Morro do Pilar. MZUSP 2760 (holotype);

Atracts edioi - Brazil: Goiás: Minaçu. MZUSP 13371 (holotype);

Atractus elaps - Brazil: Rondônia: Porto Velho. MZUSP 3156;

Atractus insipidus - Rondônia: CEPB 2951

Atractus poeppigi - Brazil: Amazonas: Manaus. IMTM 1039;

Atractus potschi - Sergipe: Salgado. MZUSP 7275

Atractus reticulatus - Rio Grande do Sul: Colônia São Lorenzo. BMNH 1946.1.2.7 (holotype);

Atractus taeniatus - Rondônia. CEPB 3121;

Atractus trilineatus - Amazonas - Novo Airão. IMTM 1328;

Atractus occiptoalbus - Andes do Ecuador. ZSM 1395

\section{REFERENCES}

[1] Peter Uetz. 2016. The Reptile Database, http://www.reptile-database.org, accessed April 10, 2016.

[2] Passos, P., Dobiey, M. \& Venegas PJ. 2010a. Variation and natural history notes on giant ground snake, Atractus gigas (Serpentes: Dipsadidae). South American Journal of Herpetology, $\quad 5$, 73-82. DOI: http://dx.doi.org/10.2994/057.005.0201

[3] Passos, P., Fernandes, R., Bernils, R. S. \& Moura-Leite JC. 2010b. Revision of the Atlantic Forest Atractus (Reptilia: Serpentes: Dipsadidae). Zootaxa, 2364, 1-63.

[4] Savage J. M. 1960. A Revision of the Ecuadorian snakes of the colubrid genus Atractus. Miscellaneous Publications Museum of Zoology, University of Michigan, 92pp.

[5] Hoogmoed, M. S. 1980. Revision of the genus Atractus in Surinam, with the resurrection of two species (Colubridae, Reptilia). Zoologische Verhandelingen, 175, 1-47. http://www.repository. naturalis.nl/ document/155376

[6] Martins, M. \& Oliveira, M. E. 1993. The snakes of the genus Atractus Wagler (Reptilia: Squamata: Colubridae) from the Manaus region, central Amazonia, Brazil. Zoologische mededelingen, 67 (2), 21-40 http://www.repository.naturalis.nl/record/318525 
[7] Haad, J. J. S. 2004. Las serpientes del género Atractus Wagler, 1828 (Colubridae, Xenodontinae) en la Amazonia Colombiana. Revista de la Academia Colombiana de Ciencias Exactas, Físicas y Naturales, 28(108), 1-446. http://www.accefyn.org.co/revista/Vol_28/108/10_409_\%20446.pdf

[8] Passos, P. \& Lynch, J. D. 2010. Revision of Atractus (Serpentes: Dipsadidae) from Middle and Upper Magdalena Drainage of Colombia. Herpetological Monographs, 24(1), 149-173. DOI: http://dx.doi.org/10.1655/09-041.1

[9] Passos, P., Kok, P. J. R., Albuquerque, N. R. de,\& Rivas, G. A. 2013b. Ground snakes of the Lost World: A Review of Atractus (Serpentes: Dipsadidae) from the Pantepui Region, Northern South America. Herpetological Monographs, 27(1), 52-86. DOI: 10.1655/HERPMONOGRAPHS-D12-00001R2.1

[10] Prudente, A. L. C \& Santos-Costas, M. C. 2006. A new species of Atractus Wagler, 1828 (Serpentes: Colubridae) from Eastern Amazonia, Brazil. Zootaxa, 1285, 21-29 https://www.researchgate.net/publication/255522670_A_new_species_of_Atractus_Wagler_182 8_Serpentes_Colubridae_from_Eastern_Amazonia_Brazil

[11] Passos, P., Fernandes, D. S. \& Borges-Nojosa, D. M. 2007. A New Species of Atractus (Serpentes: Dipsadinae) from a Relictual Forest in Northeastern Brazil. Copeia, 4, 788-797. https://www.jstor.org/stable/25140697?seq=1\#page_scan_tab_contents

[12] Cacciali, P., Villalba, R., \&Yanosky, A. A. 2007. A new species of Atractus (Serpentes: Colubridae: Dipsadinae) from the Atlantic forest of alto Paraná, Paraguay. South American Journal of Herpetology, 2(2), 83-88. DOI: 10.1206/0003-0082(2003)391<0001: RSFNSF> 2.0.CO;2

[13] Prudente, A. L \& Passos, P. 2010. New Cryptic Species of Atractus (Serpentes: Dipsadidae) from Brazilian Amazonia. Copeia, 3, 397-404 http://www.herpetologiamuseunacional.com.br/ pdfs/paulo_passos/Prudente_e_Passos_2010.pdf

[14] Passos, P., Teixeira, Jr. M., Recoder, R. S., Sena, M. A., Dal Vechio, F., Pinto, H. B. A., Mendonca, S. H. S. T., Cassimiro, J. \& Rodrigues, M. T. 2013. A new species of Atractus (Serpentes:Dipsadidae) from Serra do Cipó, Espinhaco Range, Southeastern Brazil, with proposition of a new species group to the genus. Papéis Avulsos de Zoologia: Museu de zoologia da Universidade de São Paulo, 53 (6), 75-85. http://dx.doi.org/10.1590/S003110492013000600001

[15] Köhler, G. \& Kieckbusch, M. 2014. Two new species of Atractus from Colombia (Reptilia, Squamata, Dipsadidae). Zootaxa. 3872 (3), 291-300. DOI: 10.11646/zootaxa.3872.3.5.

[16] Salazar-Valenzuela, D., Torres-Carvajal, O.\& Passos, P. 2014. A New Species of Atractus (Serpentes: Dipsadidae) from the Andes of Ecuador. Herpetologica, 70(3), 350-363. doi: http://dx.doi.org/10.1655/HERPETOLOGICA-D-13-00045

[17] Maniatis T., Fritsch E. F., Sambrook J. 1982. Molecular cloning: a laboratory Manual. New York: Cold spring Harbor Laboratory. 545 p. http://www.cshlpress.com/ pdf/sample/2013/ MC4/MC4FM.pdf

[18] Palumbi, S. R., Martin, A., Romano, S., McMillan, W. O., Stice, L. \& Grabowski, G. 1991. "The Simple Fool's Guide to PCR, Version 2.0." Privately published document compiled by S. Palumbi, Dept. Zoology, Univ. Hawaii. http://palumbi.stanford.edu/SimpleFoolsMaster.pdf

[19] Thompson, J. D., Higgins, D. G. \& Gibson, T. J. 1996. CLUSTAL W: improving the sensitivity of progressive multiple sequence alignment through sequence weighting, position specific gap penalties and weight matrix choice. Nucleic Acids Research, 22, 4673-4680. http://www.ncbi.nlm.nih.gov/pmc/articles/PMC308517/pdf/nar00046-0131.pdf

[20] Hall, T. A. 1999. BioEdit: a user-friendly biological sequence alignment editor and analysis program for Windows 95/98/NT. Nucleic Acids Symposium Series, 41, 95-98. http://brownlab.mbio.ncsu.edu/JWB/papers/1999Hall1.pdf

[21] Darriba, D., Taboada, G. L, Doallo, R. \& Posada, D. 2012. "jModelTest 2: more models, new heuristics and parallel computing". Nature Methods 9 (8), 772. DOI:10.1038/nmeth.2109

[22] Jobb, G. 2008. TREEFINDER version of March of 2011. Munich, Germany. Distributed by the author at www.treefinder.de. (Accessed 30 of June 2014).

[23] Tamura, K., Dudley, J., Nei, M. \& Kumar, S. 2007. MEGA 6.0: Molecular Evolutionary Genetics Analysis (MEGA) software version 4.0. Molecular Biology and Evolution, 24, 1596-1599. http://www.megasoftware.net/pdfs/TamuraKumar07.pdf 
[24] Zaher, H. \& Prudente, A. L. C. 2003. Hemipenis of Siphlophis (Serpentes: Xenodontinae) and techniques of hemipenial preparation in snakes: a response to Dowling. Herpetological Review, 34 ,

295-302. https://www.researchgate.net/publication/255522587_Hemipenes_of_Siphlophis_Serpentes_Xen odontinae_and_Techniques_of_Hemipenial_Preparation_in_Snakes_A_Response_to_Dowling

[25] Passos, P., Prudente, A. L. C. \& Lynch, J. D. 2016. Redescription of Atractus punctiventris and Description of Two New Atractus (Serpentes: Dipsadidae) from Brazilian Amazonia. Herpetological Monographs, 30(1):1-20.DOI: http://dx.doi.org/10.1655/HERPMONO GRA PHS-D-14-00009

[26] Padial, J. M. \& De La Riva, I. 2009. Integrative taxonomy reveals cryptic Amazonian species of Pristimantis (Anura: Strabomantidae). Zoological Journal of the Linnean Society 155, 97-122. DOI: 10.1111/j.1096-3642.2008.00424.x

[27] Funk, W. C., Caminer, M. \& Ron, S. R. 2011. High levels of cryptic species diversity uncovered in Amazonian frogs. Proceedings of the Royal Society B: Biological Sciences 279, 1806-1814. DOI: 10.1098/rspb.2011.1653

[28] Gamble, T., Collic, G. R., Rodrigues, M. T., Wernecke, F. P. \& Simons, A. M. 2011. Phylogeny and cryptic diversity in geckos (Phyllopezus; Phyllodactylidae; Gekkota) from South America's open biomes. Molecular Phylogenetics and Evolution, 62(3), 943-953. DOI:10.1016/ j.ympev. 2011.11.033

[29] De Oliveira, D. P., de Carvalho, V. T. \& Hrbek, T. 2016. Cryptic diversity in the lizard genus Plica (Squamata): phylogenetic diversity and Amazonian biogeography. Zoologica Scripta, 00, 000-000. DOI: 10.1111/zsc. 12172

[30] Kuch, U., Keogh, S. J., Weigel, J., Smith, L.A. \& Mebs, D. 2005. Phylogeography of Australians king brown snake (Pseudechis australis) reveals Pliocene divergence and Pleistocene dispersal of a top predator. Naturwissenschaften, 92, 121-127. DOI 10.1007/s00114-004-0602-0

[31] Daniels, S. R., Heidman, N. J. L. \& Hendricks, M. G. J. 2009. Examinations of evolutionary relationships in the Cape fossorial skink species complex (Acontinae: Acontias meleagris meleagris) reveals the presence of five cryptic lineages. Zoologica Scripta, 38, 449-463. DOI:10.1111/j.1463-6409.2009.00387.x

[32] Schargel, W. E. \& Castoe, T. A. 2003. The hemipenis of some snakes of the semifossorial genus Atractus, with comments on variation in the genus. Journal of Herpetology, 37, 718-721. DOI: $10.1670 / 7-02 \mathrm{~N}$ 